\title{
Analysis of recombinant Duffy protein-linked N-glycans using lectins and glycosidases*
}

\author{
Magdalena Grodecka, Marcin Czerwiński, Maria Duk, Elwira Lisowska and \\ Kazimiera Waśniowska ${ }^{\bowtie}$
}

Department of Immunochemistry, Ludwik Hirszfeld Institute of Immunology and Experimental Therapy, Polish Academy of Sciences, Wroclaw, Poland

\begin{abstract}
Duffy antigen is a glycosylated blood group protein acting as a malarial and chemokine receptor. Using glycosylation mutants we have previously demonstrated, that all three potential glycosylation sites of the Duffy antigen are occupied by $\mathrm{N}$-linked oligosaccharide chains. In this study, wild-type Duffy glycoprotein and three mutants, each containing a single $\mathrm{N}$-glycan, were used to characterize the oligosaccharide chains by lectin blotting and endoglycosidase digestion. The positive reaction of all the recombinant Duffy forms with Datura stramonium and Sambucus nigra lectins showed that each Duffy Nlinked glycan contains Gal $\beta 1-4 G I c N A c$ units terminated by (a2-6)-linked sialic acid residues, typical of complex oligosaccharides. The reactivity with Aleuria aurantia and Lens culinaris lectins suggested the presence of (a1-6)linked fucose at the N-glycan chitobiose core. The failure of the Galanthus nivalis and Canavalia ensiformis lectins to bind to any of the Duffy mutants or to the wild-type antigen indicated that none of the three Duffy N-glycosylation sites carries detectable levels of high-mannose oligosaccharide chains. Digestion of Duffy samples with peptide $\mathrm{N}$-glycosidase $\mathrm{F}$ and endoglycosidase $\mathrm{H}$ confirmed the presence of $\mathrm{N}$-linked complex oligosaccharides. Our results indicate that Duffy antigen N-glycans are mostly core-fucosylated complex type oligosaccharides rich in $\mathrm{N}$-acetyllactosamine and terminated by (a26)-linked sialic acid residues.
\end{abstract}

Keywords: Duffy antigen, chemokine receptor, chemokines, N-glycosylation, lectins

Received: 30 August, 2009; revised: 06 February, 2010; accepted: 12 March, 2010; available on-line: 16 March, 2010

\section{INTRODUCTION}

Duffy antigen/receptor for chemokines (DARC) is a seven-transmembrane $\mathrm{N}$-glycosylated protein present mainly on erythrocytes and endothelial cells of post-capillary venules of various tissues. Initially identified as a blood group antigen, it was later characterized as a receptor for Plasmodium vivax parasites and a promiscuous chemokine-binding protein. The polypeptide chain of the Duffy glycoprotein consists of 336 amino-acid residues and spans the cell membrane seven times, creating three extra- and three intracellular loops. The N-terminal glycosylated extracellular domain carries the Duffy blood group antigens $\mathrm{Fy}^{\mathrm{a}}$ and $\mathrm{Fy}^{\mathrm{b}}$, which differ by an amino acid at position 42 (Fya-Gly, Fyb-Asp), as well as a common Fy6 epitope (Hadley \& Peiper, 1997; Pogo \& Chaudhuri, 2000; Rot \& Horuk, 2009). The Fy6 epitope, recognized by a number of monoclonal antibodies, is located within amino-acid residues 19-26 of the Duffy polypeptide chain (Waśniowska et al., 1996; 2002). The extracellular domain of DARC is particularly interesting because it has been shown to be involved in the interaction with chemokines and $P$. vivax parasite (Horuk et al., 1993; Tournamille et al., 1997; Choe et al., 2005). Nearly all West Africans lack Duffy antigen on erythrocytes due to a mutation in the erythroid promoter region, which makes them resistant to $P$. vivax malaria infection. However, Duffy expression is retained on non-erythroid tissues, suggesting the importance of this antigen (Peiper et al., 1995; Tournamille et al., 1995).

DARC acts as a promiscuous receptor for a number of pro-inflammatory CC and CXC chemokines but apparently has no signal transduction ability (Horuk et al., 1993; Gardner et al., 2004). For this reason it was designated as a "silent" chemokine receptor or, more recently, as a member of the "interceptors" family (Nibbs et al., 2003; Grodecka \& Waśniowska, 2007). Nevertheless, DARC may play some role in inflammatory reactions, acting as a chemokine scavenger on the red blood cell surface and, expressed in endothelial cells, as a regulator of induced leukocyte trafficking (Darbonne et al., 1991; Pruenster et al., 2008). Moreover, it has been suggested that Duffy antigen may inhibit tumor progression and metastasis in prostate and breast cancer (Shen et al., 2006; Wang et al., 2006). There are also controversial reports on the role of DARC in HIV-1 infection (He et al., 2008; Winkler et al., 2009).

The role of the Duffy antigen is only partially elucidated and its more detailed biophysical and structural characterization would be important for understanding its various functions. DARC is a sialylated glycoprotein which has a strong tendency to form aggregates, even under denaturing conditions, and migrates in polyacrylamide gel as a wide band of $36-46 \mathrm{kDa}$ (Hadley et al., 1984; Tanner et al., 1988; Waśniowska et al., 1993). This report is focused on Duffy antigen glycosylation, which has not yet been thoroughly studied. Duffy protein has three potential $\mathrm{N}$-glycosylation sites, all located in the N-terminal extracellular domain at Asn16, Asn27, and Asn33, and it was reported that only two of them are occupied (Tournamille et al., 2003). However, our recent studies on Duffy glycosylation mutants have demon-

\footnotetext{
\e-mail: wasniows@iitd.pan.wroc.pl

*Part of results was presented at the Congress of Biochemistry and Cell Biology, Olsztyn, September 7th-11th, 2008, Poland. Abbreviations: PNGase, peptide N-glycosidase; TBS, Tris-buffered saline; TTBS, 0.5 Tween-20 in TBS.
} 
strated the presence of oligosaccharide chains in all three positions (Czerwiński et al., 2007; Grodecka et al., 2008). In the present study we further characterize the recombinant Duffy protein N-glycans by probing the Duffylinked carbohydrate moieties with lectins and by endoglycosidase digestion. Our results indicate that Duffy oligosaccharide chains contain $N$-acetyllactosamine units terminating with $(\alpha 2-6)$-linked sialic acid residues, which are characteristic of complex-type N-glycans, with ( $\alpha 1$ $6)$-fucose on the N,N'-diacetylchitobiose core. To the best of our knowledge, this is the first report approximating the structure of the recombinant Duffy antigen oligosaccharides.

\section{MATERIALS AND METHODS}

Purification of recombinant Duffy protein. K562 cell lines expressing mutated Duffy proteins were established and cultured as described previously (Czerwiński et al., 2007). Briefly, four lines of K562 cells stably expressing recombinant Duffy proteins, i.e., a wild-type form and three forms with two of the three glycosylation sites mutated (designated S18A.S29A, S18A.S35A, S29A.S35A), were grown to $10^{9}$ cells, harvested by centrifugation, washed twice in ice-cold PBS (phosphatebuffered saline), and lysed in $8 \mathrm{ml}$ of CelLytic buffer (Sigma-Aldrich). The lysates were cleared by centrifugation at $15000 \times \mathrm{g}$ for $20 \mathrm{~min}$ at $4^{\circ} \mathrm{C}$ and used for Duffy purification (or frozen at $-80^{\circ} \mathrm{C}$ ). The supernatant was collected and incubated with an equal volume of extraction buffer (40 mM phosphate buffer $\mathrm{pH} 8.0,300 \mathrm{mM}$ $\mathrm{NaCl}, 20 \%$ (v/v) glycerol, $2 \%$ n-dodecyl- $\beta$-D-maltoside (DDM), protease inhibitors) at $4{ }^{\circ} \mathrm{C}$ for $2 \mathrm{~h}$ on a rotator to extract the Duffy protein. After centrifuging at $19000 \mathrm{rpm}$. $(28000 \times \mathrm{g})$ for $45 \mathrm{~min}$ at $4^{\circ} \mathrm{C}$, the supernatant was collected and used for further purification of recombinant DARC proteins.

Ni-NTA agarose $(0.5 \mathrm{ml}$; Qiagen $)$ was packed in a column, equilibrated with $5 \mathrm{ml}$ of $20 \mathrm{mM}$ phosphate buffer $\mathrm{pH}$ 8.0, $150 \mathrm{mM} \mathrm{NaCl}, 0.1 \%$ DDM, and $10 \%$ $(\mathrm{v} / \mathrm{v})$ glycerol, and incubated with clarified supernatant at $4{ }^{\circ} \mathrm{C}$ for $2 \mathrm{~h}$ on a rotator. Protein bound to the resin was eluted with $5 \mathrm{ml}$ of equilibration buffer containing $300 \mathrm{mM}$ imidazole and collected in $0.5 \mathrm{ml}$ aliquots. Fractions identified in dot blot as Duffy-positive were combined, diluted 20-fold with equilibration buffer to reduce the imidazole concentration to $15 \mathrm{mM}$, and applied on an equilibrated $0.5 \mathrm{ml}$ Talon Metal Affinity Resin column (Clontech). The column was washed with $15 \mathrm{ml}$ of equilibration buffer and the protein was eluted in $0.5 \mathrm{ml}$ fractions using $5 \mathrm{ml}$ of $150 \mathrm{mM}$ imidazole in the equilibration buffer. DARC-positive fractions were identified by dot blotting and combined. All extraction and purification steps were performed at $4^{\circ} \mathrm{C}$ with Complete EDTA-free protease inhibitor cocktail tablets (Roche) and protease inhibitor cocktail (Sigma-Aldrich) added.

SDS/PAGE and Western blotting. SDS/PAGE was performed in 12\% polyacrylamide gels (Laemmli, 1970) followed by protein transfer to an Immobilon-P membrane. The membrane was blocked for $4 \mathrm{~h}$ at room temperature with TBS (Tris-buffered saline) containing $5 \%$ bovine serum albumin and $0.3 \%$ Tween-20 (BioRad). Blotted Duffy protein was identified by consecutive incubations with anti-Fy6 2C3 monoclonal antibody (Waśniowska et al., 2002; overnight at $4{ }^{\circ} \mathrm{C}$ ), alkaline phosphatase-conjugated goat anti-mouse $\operatorname{IgG}$ antibody (Bio-Rad; $1 \mathrm{~h}$, room temp.), and phosphatase substrate solution: $0.15 \mathrm{mg} / \mathrm{ml} \mathrm{BCIP}$ (5-bromo-4-chloro-3-indolyl phosphate $p$-toluidine salt) and $0.3 \mathrm{mg} / \mathrm{ml} \mathrm{NBT}(p-\mathrm{Ni}-$ troblue Tetrazolium chloride, Bio-Rad) in $0.1 \mathrm{M}$ Tris/ $\mathrm{HCl} \mathrm{pH}$ 9.5, $1 \mathrm{mM} \mathrm{MgCl}_{2}$ buffer.

Lectin blotting. Purified Duffy recombinant variants were subjected to SDS/PAGE followed by blotting onto Immobilon-P membrane (Millipore). The membrane was incubated in Blocking Reagent (Roche) or in $0.5 \%$ Tween-20 in TBS pH 7.4, overnight at $4{ }^{\circ} \mathrm{C}$. Then the blots were incubated with digoxigenin-conjugated lectins: Datura stramonium agglutinin (DSA), Galanthus nivalis agglutinin (GNA), Sambucus nigra agglutinin (SNA), and Mackia amurensis agglutinin (MAA; DIG Glycan Differentiation Kit, Roche), $1 \mu \mathrm{g} / \mathrm{ml}$ each in T'TBS $(0.05 \%$ Tween-20 in TBS) containing $1 \mathrm{mM} \mathrm{MgCl}_{2}, 1 \mathrm{mM}$ $\mathrm{MnCl}_{2}$, and $1 \mathrm{mM} \mathrm{CaCl}$, or with biotinylated lectins: Aleuria aurantia agglutinin (AAA), Ulex europaeus agglutinin (UEA), Ricinus communis agglutinin (RCA), Psathyrella velutina agglutinin (PVA), Canavalia ensiformis agglutinin (ConA), and Lens culinaris agglutinin (LCA; Vector Laboratories), $5 \mu \mathrm{g} / \mathrm{ml}$ each in $0.5 \%$ Tween-20/TBS $\mathrm{pH} 7.5$ or $\mathrm{pH} 8.0$ for $\mathrm{AAA}$, with $1 \mathrm{mM} \mathrm{MgCl}_{2}, 1 \mathrm{mM} \mathrm{MnCl}_{2}$, and $1 \mathrm{mM} \mathrm{CaCl}$. Incubation was performed at room temp. for $2 \mathrm{~h}$ with gentle shaking. The blots were washed $6 \times 10$ min with $0.5 \%$ Tween-20 in TBS pH 7.5, and incubated with either anti-digoxigenin-alkaline phosphatase conjugate diluted 1:1000 (Roche) or alkaline phosphatase-conjugated ExtrAvidin diluted 1:10000 (SigmaAldrich) for $1 \mathrm{~h}$ at room temp. with gentle shaking. The color reaction was developed using standard $\mathrm{BCIP} / \mathrm{NBT}$ conditions. The specificity of AAA binding was verified by preincubating the lectin in a buffer containing an excess of competing sugar $(0.7 \mathrm{M} \mathrm{L}$-fucose) for $2 \mathrm{~h}$ at room temp. The specificities of SNA, RCA, and PVA were examined by reaction with the blotted Duffy proteins after consecutive removal of sialic acid and galactose residues. The lectins and their specificities are listed in Table 1 (Wu et al., 2001).

Modification of blotted proteins. Desialylation was done by treating Immobilion-P membrane after protein transfer with $0.025 \mathrm{M}$ sulfuric acid for $1 \mathrm{~h}$ at $80^{\circ} \mathrm{C}$. Degalactosylation was performed after desialylation by incubating the blots successively in (i) $0.05 \mathrm{M} \mathrm{NaIO}_{4}$ in 0.1 $\mathrm{M}$ acetate buffer, $\mathrm{pH} 4.5$, overnight at $4{ }^{\circ} \mathrm{C}$, (ii) $0.15 \mathrm{M}$ $\mathrm{NaBH}_{4}$ in $0.1 \mathrm{M}$ sodium borate buffer, $\mathrm{pH} 8.0$, for $2-3 \mathrm{~h}$ at $20^{\circ} \mathrm{C}$, and (iii) $0.025 \mathrm{M}$ sulfuric acid for $1 \mathrm{~h}$ at $80^{\circ} \mathrm{C}$. Each incubation was followed by washing the blots with water. After modification, the blots were blocked and analyzed by lectin binding (Wu et al., 2008).

Endoglycosidase treatment. Endoglycosidase digestion was performed following protocols provided by the enzyme suppliers. Recombinant Duffy proteins were incubated overnight at $37^{\circ} \mathrm{C}$ with PNGase F (peptide $N$ glycosidase F) or endoglycosidase H (both from SigmaAldrich) in the presence of protease inhibitors. The reaction was terminated by boiling the sample for $5 \mathrm{~min}$ and adding Laemmli electrophoresis sample buffer. Digested protein was analyzed by immunoblotting.

\section{RESULTS AND DISCUSSION}

\section{Lectin-binding analysis of purified Duffy proteins}

Duffy glycoproteins were stably expressed in K562 cells, isolated and purified by immobilized metal affinity chromatography (IMAC). The investigated protein variants included a wild-type form with three $\mathrm{N}$-glycans and three mutants in which two glycosylation sites (Asn- 


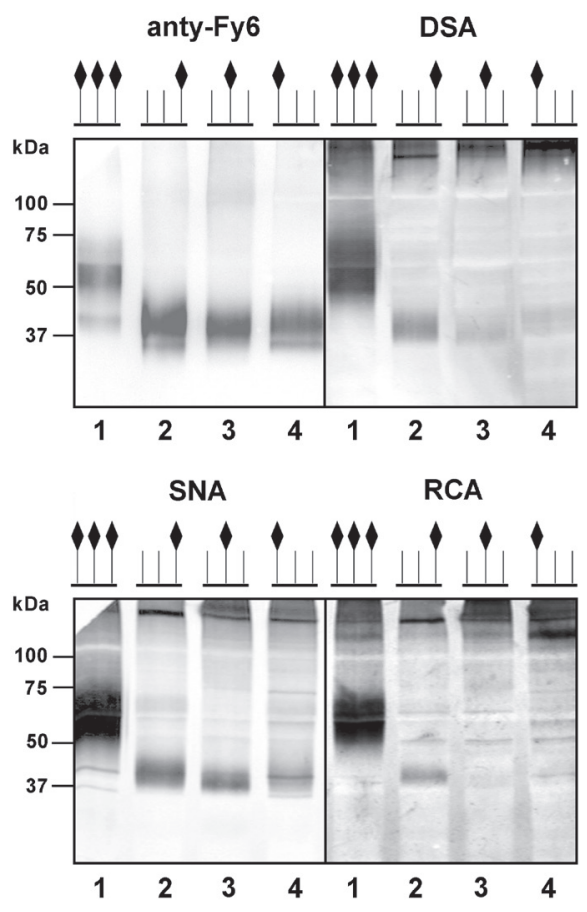

Figure 1. Western blotting analysis of recombinant Duffy proteins

Purified proteins were separated by SDS/PAGE, transferred to Immobilon-P membrane, and identified with $2 \mathrm{C} 3$ anti-Fy6 monoclonal antibody or DSA, SNA and RCA lectins. RCA binding was performed after treating the blot with $0.025 \mathrm{M}$ sulfuric acid for $1 \mathrm{~h}$ at $80^{\circ} \mathrm{C}$. Lanes: 1 , wild-type Duffy protein; $2-4$, double mutants: 2 , S18A.S29A; 3, S18A.S35A; 4, S29A.S35A.

X-Ser) were inactivated by replacement of the Ser residue by Ala. Each of these mutants contained a single N-glycan at Asn33 (S18A.S29A), Asn27 (S18A.S35A), or Asn16 (S29A.S35A) (Czerwiński et al., 2007). The Duffy glycoproteins were detected on the blots using antiDuffy monoclonal antibody (2C3), and lectin blotting assays were performed in parallel.

The strongest reactions were observed with DSA, which binds specifically to Galß1-4GlcNAc, and SNA, which recognizes terminal ( $\alpha 2-6)$-linked sialic acid (Fig. 1). Removing the sialic acid residues from the blotted proteins by mild acid hydrolysis completely abolished SNA binding (not shown), which confirmed the pres-

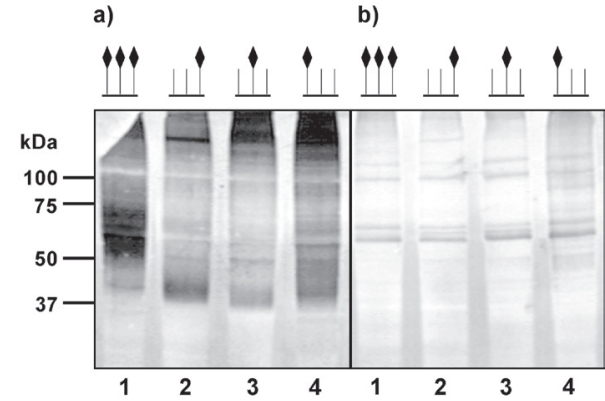

Figure 2. Aleuria aurantia lectin binding to recombinant Duffy proteins

Purified Duffy proteins were separated by SDS/PAGE and transferred to Immobilon-P membrane. The blots were incubated with AAA: $a$ ) in the absence of competing sugar, b) in the presence of 0.7 M L-fucose. Lanes: 1, wild-type Duffy protein; 2, S18A.S29A; 3, S18A.S35A; 4, S29A.S35A.

ence of sialic acid residues. Both lectins were bound to the wild-type Duffy and its three variant forms, indicating that each $\mathrm{N}$-linked glycan on Duffy protein contains lactosamine units (Galß1-4GlcNAc) and terminal $(\alpha 2-6)$-linked sialic acid typical of complex-type oligosaccharides. A negative reaction on the blot with MAA excluded the presence of terminal ( $\alpha 2-3)$-linked sialic acid. RCA, which detects terminal galactose residues, particularly in Galß1-4GlcNAc units, reacted with the Duffy bands only after desialylation (Fig. 1). A weak reaction was observed for PVA after desialylation and degalactosylation (not shown), confirming the presence of GlcNAc residues in the chains.

Aleuria aurantia lectin, which binds specifically to $(\alpha 1$ $6)$-linked fucose and, to a lesser extent, to ( $\alpha 1-2)$ - and ( $\alpha 1-3)$-linked fucose, reacted strongly with all the recombinant Duffy forms, indicating the presence of fucose residues in the oligosaccharide chains. The specificity of lectin binding was confirmed by the absence of binding when AAA was preincubated with $0.7 \mathrm{M}$ L-fucose (Fig. 2). The positive reaction with LCA (not shown), which interacts strongly with core-fucosylated complex $\mathrm{N}$-glycans, indicated that the presence of ( $\alpha 1-6)$-linked fucose in the chitobiose core of the Duffy oligosaccharides is highly likely.

No reaction on the blot was observed with $\alpha$-Manspecific lectins such as GNA and ConA, which suggests a lack of high-mannose type chains in the recombinant

Table 1. Lectin binding to purified recombinant Duffy proteins

\begin{tabular}{llc}
\hline Lectin & Specificity & Binding to Duffy proteins \\
\hline AAA, Aleuria aurantia agglutinin & Fuc (a1-6)>>(a1-2), (a1-3) & ++ \\
ConA, Canavalia ensiformis agglutinin & aMan, branched Man & - \\
DSA, Datura stramonium agglutinin & Galß1-4GlcNAc & ++ \\
GNA, Galanthus nivalis agglutinin & aMan, terminal Man & - \\
LCA, Lens culinaris agglutinin & aMan, aGlc, core - fucosylated N-glycans & + \\
MAA, Maackia amurensis agglutinin & Neu5Ac (a2-3) & - \\
PVA, Psathyrella velutina agglutinin & GlcNAc & $+*$ \\
RCA, Ricinus communis agglutinin & terminal Gal & $+{ }^{* *}$ \\
SNA, Sambucus nigra agglutinin & Neu5Ac (a2-6) & ++ \\
UEA, Ulex europaeus agglutinin & Fuc (a1-2) & - \\
\hline
\end{tabular}

"Lectin specificities according to Wu et al., 2001; ${ }^{(+)}$strong binding, ${ }^{(+)}$weak binding, ${ }^{(-)}$no binding; ${ }^{(*)}$ after desialylation and degalactosylation, ${ }^{(* *)}$ after desialylation 


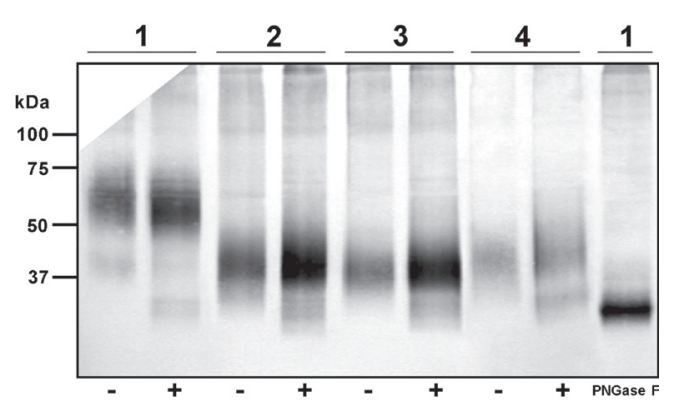

Figure 3. Western blotting analysis of purified recombinant Duffy proteins treated with endoglycosidase $\mathrm{H}$

Four recombinant proteins were digested with endoglycosidase $\mathrm{H}$, separated by SDS/PAGE, transferred to Immobilon-P membrane, and identified with $2 \mathrm{C} 3$ anti-Fy6 monoclonal antibody. Lanes: 1, wild-type Duffy protein; 2, S18A.S29A; 3, S18A.S35A; 4, S29A.S35A; - or +, samples not treated or treated with the enzyme, respectively. Last lane presents wild-type Duffy protein digested with PNGase F.

Duffy glycoprotein. ConA shows the strongest reactivities with oligomannosidic structures, including the common trimannoside core of N-glycans (Bhattacharyya \& Brewer, 1989). ConA recognizes this core structure in some complex N-glycans with lower affinity. The lack of ConA reactivity with Duffy $\mathrm{N}$-glycans suggests that they may have extensive repeating Gal $\beta 1-4 G l c N A c$ units, more than two antennas or a bisecting ( $\beta 1-4)$-linked GlcNAc residue at the core.

The results of the lectin-binding analysis are summarized in Table 1. Some lectins showed various staining intensities of the three Duffy mutants (Figs. 1 and 2), but a weaker staining of the about $40 \mathrm{kDa}$ Duffy band was accompanied by a stronger staining of aggregates. Therefore these results rather reflect glycosylation sitedependent differences in the tendency of Duffy mutants to aggregate and not site-specific differences in the structure of the N-glycans. Staining with lectins and the lack of staining of the aggregates with anti-Fy6 antibody (Fig. 1) might result from steric hindrance of the Fy6 epitope and exposure of the oligosaccharide chains in the aggregated glycoproteins.

\section{Endoglycosidase treatment of recombinant Duffy proteins}

The results obtained with lectins suggested that all N-glycans of the Duffy protein were complex oligosaccharides and that high-mannose chains were not present. To apply a different approach to this problem, the recombinant proteins were treated with PNGase F, which cleaves all types of $\mathrm{N}$-glycan chains from the protein backbone, and with endoglycosidase $H$, which cleaves only high-mannose and hybrid oligosaccharides. Western blot analysis of the digested proteins indicated that complete deglycosylation of the four recombinant Duffy proteins after PNGase F treatment resulted in the generation of a protein of about $35 \mathrm{kDa}$ molecular mass, corresponding to the mass of the deglycosylated recombinant Duffy form (Czerwiński et al., 2007). Endoglycosidase $\mathrm{H}$ digestion produced no change in the electrophoretic mobility of the major bands of all the Duffy recombinants. However, this treatment of all the recombinants, including the wild-type Duffy with three N-glycans, produced a faint band (not seen in untreated samples) with the mobility of the totally deglycosylated about $35 \mathrm{kDa}$ Duffy protein (Fig. 3). This result suggested that most molecules of the Duffy recombinants contain N-glycans of a complex type, and the minor fraction of molecules which were totally sensitive to endoglycosidase $\mathrm{H}$ treatment contain only high-mannose or hybrid-type chains. This minor subfraction may reflect the presence of a small number of intracellular, not fully processed Duffy molecules which, due to their low abundance, were undetectable in the total pool of Duffy recombinants with Man-specific lectins.

Glycosylation is significant for protein folding and properties of adhesive proteins and receptors (Gutierrez et al., 2004; Janik et al., 2010). To date, glycosylation of several chemokine receptors has been reported and shown to be important for ligand binding and HIV entry through the CCR5 and CXCR4 receptors but the oligosaccharide chain structures of chemokine receptors are still unknown (Preobrazhensky et al., 2000; Bannert et al., 2001; Blackburn et al., 2004; Huskens et al., 2007). Determining the detailed molecular structures of chemokine receptors and the mechanism of ligand-receptor interaction remains an enormous challenge, mainly due to the difficulty in obtaining satisfactory quantities of pure proteins.

Enzymatic digestion and lectins with well-defined specificity are excellent tools for identifying and characterizing glycans when the amount of biological material is not sufficient for instrumental analysis (CiołczykWierzbicka et al., 2002). We could not investigate the detailed structures of the Duffy oligosaccharide chains by instrumental techniques due to the lack of an efficient expression system for the preparation of posttranslationally modified integral membrane protein in the large quantity required for structural studies using NMR or GC-MS spectroscopy. The strong tendency of native Duffy to form homo- and hetero-oligomers, which leads to aggregation and great loss of the protein, is an additional obstacle, typical for all chemokine receptors (Hadley et al., 1984; Waśniowska et al., 1993).

In conclusion, the results obtained by lectin blotting analysis and glycosidase digestion suggest that the oligosaccharide chains in all the forms of recombinant Duffy protein are complex type $\mathrm{N}$-glycans with core $(\alpha 1-6)$ fucosylation, rich in lactosamine units (Gal $\beta 1$ $4 \mathrm{GlcNAc})$ terminated by $(\alpha 2-6)$-linked sialic acid residues. Our results indicate that detectable levels of highmannose oligosaccharide chains are not present at any of the three Duffy N-glycosylation sites. No conclusive evidence was obtained for glycosylation site-specific differences in the structures of the three $\mathrm{N}$-glycans of the Duffy protein.

\section{Acknowledgements}

This work was supported by grant 2 P05A 01830 from the Ministry of Science and Higher Education.

\section{REFERENCES}

Bannert N, Craig S, Farzan M, Sogah D, Santo NV, Choe H, Sodroski J (2001) Sialylated O-glycans and sulfated tyrosines in the NH2terminal domain of $\mathrm{CC}$ chemokine receptor 5 contribute to high affinity binding of chemokines. J Exp Med 194: 1661-1673.

Bhattacharyya L, Brewer CF (1989) Interactions of concanavalin A with asparagine-linked glycopeptides. Structure/activity relationships of the binding and precipitation of oligomannose and bisected hybrid-type glycopeptides with concanavalin A. Eur J Biochem 178: 721-726.

Blackburn PE, Simpson SV, Nibbs RJB, O'Hara M, Booth R, Poulos J, Isaacs NW, Graham GJ (2004) Purification and biochemical characterization of the D6 chemokine receptor. Biochem J 379: 263-272. 
Ciołczyk-Wierzbicka D, Gil D, Hoja-Łukowicz D, Lityńska A, Laidler P (2002) Carbohydrate moieties of N-cadherin from human melanoma cell lines. Acta Biochim Pol 49: 991-998.

Choe H, Moore MJ, Owens C, Wright PL, Vasilieva N, Li W, Singh AP, Shakri R, Chitnis EC, Farzan M (2005) Sulphated tyrosines mediate association of chemokines and Plasmodium vivax Duffy binding protein with the Duffy antigen/receptor for chemokines (DARC). Mol Microbiol 55: 1413-1422.

Czerwiński M, Kern J, Grodecka M, Paprocka M, Krop-Wątorek A, Waśniowska K (2007) Mutational analysis of the N-glycosylation sites of Duffy antigen/receptor for chemokines. Biochem Biophys Res Commun 273: 705-711.

Darbonne WC, Rice GC, Mohler MA, Apple T, Hebert CA, Valente AJ, Baker JB (1991) Red blood cells are a sink for interleukin 8, a leukocyte chemotaxin. J Clin Invest 88: 1362-1367.

Gardner L, Patterson A, Ashot B, Stone M, Middleton J (2004) The human Duffy antigen binds selected inflammatory but not homeostatic chemokines. Biochem Biophys Res Commun 321: 306-312.

Grodecka M, Waśniowska K (2007) Interceptors — "silent" chemokine receptors. Postepy Hig Med Dosw (online) 61: 231-239.

Grodecka M, Czerwiński M, Waśniowska K (2008) Analysis of the Duffy glycoprotein N-glycans: use of lectins and glycosidases. Acta Biochim Pol 55 (Suppl 3): P5.1.

Gutierrez J, Kremer L, Zaballos A, Goya I, Martinez-A C, Marquez G (2004) Analysis of post-translational CCR8 modifications and their influence on receptor activity. J Biol Chem 279: 14726-14733.

Hadley TJ, Peiper SC (1997) From malaria to chemokine receptor: the emerging physiologic role of the Duffy blood group antigen. Blood 89: 3077-3091.

Hadley TJ, David PH, McGinniss MH, Miller LH (1984) Identification of an erythrocyte component carrying the Duffy blood group Fy antigen. Science 223: 597-599.

He W, Neil S, Kulkarni H, Wright E, Agan BK, Marconi VC, Dolan MJ, Weiss RA, Ahuja SK (2008) Duffy antigen receptor for chemokines mediates trans-infection of HIV-1 from red blood cells to target cells and affects HIV-AIDS susceptibility. Cell Host Microbe 4: $52-62$.

Horuk R, Chitnis CE, Darbonne WC, Colby TJ, Rybicki A, Hadley TJ, Miller LH (1993) A receptor for malarial parasite Plasmodium vivax: The erythrocyte chemokine receptor. Science 261: 1182-1184.

Huskens D, Princen K, Schreiber M, Schols D (2007) The role of Nglycosylation sites on the CXCR4 receptor for CXCL-12 binding and signaling and X4 HIV-1 viral infectivity. Virology 363: 280-287.

Janik ME, Przybyło M, Pocheć E, Pokrywka M, Lityńska A (2010) Effect of $\alpha_{3} \beta_{1}$ and $\alpha_{v} \beta_{3}$ integrin glycosylation on interaction of melanoma cells with vitronectin. Acta Biochim Pol 57: 55-61.

Laemmli UK (1970) Cleavage of structural proteins during the assembly of bacteriophage T4. Nature 22: 680-685.

Nibbs R, Graham G, Rot A (2003) Chemokines on the move: control by the chemokine "interceptors" Duffy blood group antigen and D6. Sem Immunol 15: 287-294.

Peiper SC, Wang ZX, Neote K, Martin AW, Showell HJ, Conklyn MJ, Ogborne K, Hadley TJ, Lu ZH, Hesselgesser J, Horuk R (1995) The Duffy antigen/receptor for chemokines (DARC) is expressed in endothelial cells of Duffy negative individuals who lack the erythrocyte receptor. J Exp Med 181: 1311-1317.

Pogo AO, Chaudhuri A (2000) The Duffy protein: A malarial and chemokine receptor. Sem Hematol 37: 122-129.

Preobrazhensky AA, Dragan S, Kawano T, Gavrilin MA, Gulina IV, Chakravarty L, Kolattukudy PE (2000) Monocyte chemotactic pro- tein-1 receptor CCR2B is a glycoprotein that has tyrosine sulfation in a conserved extracellular N-terminal region. I Immunol 165: 5295-5303.

Pruenster M, Mudde L, Bombosi P, Dimitrova S, Zsak M, Middleton J, Richmond A, Graham GJ, Segerer S, Nibbs RJ, Rot A (2008) The Duffy antigen receptor for chemokines transports chemokines and supports their promigratory activity. Nat Immunol 10: 101-108.

Rot A, Horuk R (2009) DARC, the Duffy antigen receptor for chemokines. Methods Ensymol 461: 191-206.

Shen H, Schuster R, Stringer KF, Waltz SE, Lentsch AB (2006) The Duffy antigen/receptor for chemokines (DARC) regulates prostate growth. FASEB J 20: 59-64.

Tanner MJA, Anstee DJ, Mallinson G, Ridgwell K, Martin PG, Avent ND, Parsons SF (1988) Effect of endoglycosidase F-peptidyl N-glycosidase $\mathrm{F}$ preparations on the surface components of the human erythrocyte. Carbohydr Res 178: 203-212.

Tournamille C, Colin Y, Cartron JP, Le Van Kim C (1995) Disruption of a GATA motif in the Duffy gene promoter abolishes erythroid gene expression in Duffy-negative individuals. Nat Genet 10: 224 228 .

Tournamille C, Le Van Kim C, Gane P, Blanchard D, Proudfoot AE, Cartron JP, Colin Y (1997) Close association of the first and fourth extracellular domains of the Duffy antigen/receptor for chemokines by a disulfide bond is required for ligand binding. I Biol Chem 272: 16274-16280.

Tournamille C, Filipe A, Waśniowska K, Gane P, Lisowska E, Cartron JP, Colin Y, Le Van Kim C (2003) Structure-function analysis of the extracellular domains of the Duffy antigen/receptor for chemokines: characterization of antibody and chemokine binding sites. $\mathrm{Br}$ J Haematol 122: 1014-1023.

Towbin H, Staehelin T, Gordon J (1979) Electrophoretic transfer of proteins from polyacrylamide gel to nitrocellulose sheets: Procedure and some applications. Proc Natl Acad Sci USA 76: 4350-4354.

Wang J, Ou ZL, Hou YF, Luo JM, Shen ZZ, Ding J, Shao ZM (2006) Enhanced expression of Duffy antigen receptor for chemokines by breast cancer cells attenuates growth and metastasis potential. Oncogene 25: 7201-7211.

Waśniowska K, Eichenberger P, Kugele F, Hadley TJ (1993) Purification of a $28 \mathrm{kDa}$ non-aggregating tryptic peptide of the Duffy blood group protein. Biochem Biophys Res Commun 192: 366-372.

Waśniowska K, Blanchard D, Janvier D, Wang ZX, Peiper SC, Hadley TH, Lisowska E (1996) Identification of the Fy6 epitope recognized by two monoclonal antibodies in the N-terminal extracellular portion of the Duffy antigen receptor for chemokines. Mol Immunol 33: 917-923.

Waśniowska K, Petit-LeRoux Y, Tournamille C, Le Van Kim C, Cartron JP, Colin Y, Lisowska E, Blanchard D (2002) Structural characterization of the epitope recognized by the new anti-Fy6 monoclonal antibody NaM185-2C3. Trans Med 12: 205-211.

Winkler CA, An P, Johnson R, Nelson GW, Kirk G (2009) Expression of Duffy antigen receptor for chemokines (DARC) has no effect on HIV-1 acquisition or progression to AIDS in African Americans. Cell Host Microbe 5: 411-413.

Wu AM, Song SC, Tsai MS, Herp A (2001) A guide to the carbohydrate specificities of applied lectins-2 (updated in 2000). Adv Exp Med Biol 491: 551-585.

Wu AM, Lisowska E, Duk M, Yang Z (2008) Lectins as tools in glycoconjugate research. Glycoconj J, doi: 10.1007/s10719-008-9119-7. 